Discussion Paper No. 14-033

Assessing the Impact of Introducing an ACE Regime

A Behavioural Corporate Microsimulation Analysis for Germany

Katharina Finke, Jost H. Heckemeyer, and Christoph Spengel

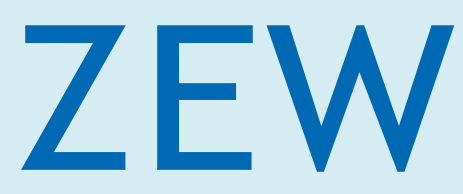

Zentrum für Europäische Wirtschaftsforschung $\mathrm{GmbH}$

Centre for European

Economic Research 
Discussion Paper No. 14-033

\title{
Assessing the Impact of Introducing an ACE Regime A Behavioural Corporate Microsimulation Analysis for Germany
}

\author{
Katharina Finke, Jost H. Heckemeyer, \\ and Christoph Spengel
}

Download this ZEW Discussion Paper from our ftp server:

http://ftp.zew.de/pub/zew-docs/dp/dp14033.pdf

Die Discussion Papers dienen einer möglichst schnellen Verbreitung von neueren Forschungsarbeiten des ZEW. Die Beiträge liegen in alleiniger Verantwortung der Autoren und stellen nicht notwendigerweise die Meinung des ZEW dar.

Discussion Papers are intended to make results of ZEW research promptly available to other economists in order to encourage discussion and suggestions for revisions. The authors are solely responsible for the contents which do not necessarily represent the opinion of the ZEW. 


\title{
Assessing the Impact of Introducing an ACE Regime
}

\author{
A Behavioural Corporate Microsimulation Analysis for Germany
}

\author{
Katharina Finke* $^{*}$ Jost H. Heckemeyer ${ }^{\dagger}$, and Christoph Spengel ${ }^{\ddagger}$
}

\begin{abstract}
May 2014
Abstract: In their famous Mirrlees review (2011) on reforming the tax system for the 21st century, the authors put forward the introduction of an allowance for corporate equity regime. In recent years, several countries introduced an $\mathrm{ACE}$ regime. The main feature of an ACE regime is that it removes tax distortions on marginal investment and finance distortions. Yet, by narrowing the tax base an ACE regime potentially requires an increase in tax rates which might affect location choices and profit shifting activity negatively. In this paper, we employ a microsimulation model to determine the consequences of introducing an ACE regime in Germany. The simulation results show that granting an ACE for corporate income tax purposes results in a revenue loss of about $18 \%$. This could be financed by an increase of the combined profit tax rate by 6 percentage points. At firm level, our analysis illustrates the heterogeneous distribution of the reform effect accross the sample. For $50 \%$ of firms between the 25th and 75th percentile, introducing an ACE regime reduces tax payments between $35 \%$ and $2 \%$. If the $\mathrm{ACE}$ is combined with a tax rate adjustment, the tax effect ranges between $-32 \%$ and $+7.1 \%$ for firms between the 25 th and 75 th percentile. With respect to behavioural responses on decision margins, we find that introducing the ACE reduces the mean debt-ratio by about 1.5 percentage points in the short run. For the capital-stock we arrive at a mean short-term increase of $2.4 \%$. Finally, our computations show that the ACE regime with adjusted profit tax rate cannot be overall tax neutral. In particular, the increase in the profit tax rate required to finance the equity allowance induces intensified outward profit-shifting activities and affects location choices negatively. In the short-run the tax revenue is therefore shown to decline to about $95 \%$ of its original level.
\end{abstract}

Keywords: Tax Reform, Allowance for Corporate Equity, Microsimulation, Tax Policy Evaluation

JEL Codes: H 25, H 32, K 34

\footnotetext{
${ }^{*}$ Centre for European Economic Research (ZEW), Corporate Taxation and Public Finance Research Unit, L7-1, 68161 Mannheim, Germany. E-mail: finke@zew.de

${ }^{\dagger}$ University of Mannheim, Chair of Business Administration and Taxation II, 68131 Mannheim, Germany. E-Mail: heckemeyer@uni-mannheim.de.

${ }^{\ddagger}$ University of Mannheim, Chair of Business Administration and Taxation II, 68131 Mannheim, Germany. E-Mail: spengel@uni-mannheim.de.
} 


\section{Introduction}

In the last two decades the economic environment was subject to fundamental changes which did not leave national tax systems unaffected. Possible options to reform national tax systems are at the heart of an ongoing political and academic debate (e.g. Mirrlees et al. (2011), de Mooij and Devereux (2011)). Conventional tax systems are known to be nonneutral since they tax an investment's full return. Against the background of the economic and financial crisis, governments have become increasingly concerned about tax distortions on financing decisions which discriminate equity finance and may lead to unduly high debt ratios. In addition, taxing the marginal return of investments has shown to be distortive and might result in an inefficient allocation of funds. In their famous Mirrlees review (Mirrlees et al. (2011)) on reforming the tax system for the 21st century, the authors put forward the introduction of an allowance for corporate equity regime. For Germany, an ACE type of reform has been proposed by the German Council of Economic Experts in their Annual Economic Report 2012 (Sachverständigenrat zur Begutachtung der gesamtwirtschaftlichen Entwicklung (2012)).

The idea of an ACE regime is not new. In the 1990th already, academics and policy makers debated the pros and cons of this reform concept. Several countries, e.g. Italy, Croatia, and Austria, actually introduced ACE type reforms in their tax systems. After several years, however, the countries abolished the ACE system, despite its compelling neutrality features with respect to financing and investment decisions. The ACE regime was considered to be hardly compatible with international tax competition putting a strong pressure on corporate income tax rates (Bond (2000)). By narrowing the tax base, the ACE regime reduces the scope for tax rate cuts. Hence, most governments rather tended to broaden the tax base and to cut tax rates. In recent years, however, the ACE concept made its comeback on the tax policy agenda. Beginning with Belgium in 2006, several countries (e.g. Latvia, Italy) introduced or reintroduced ACE regimes.

Against this background, this paper contributes to the understanding of the overall implications of an ACE regime. The analysis is based on the behavioural corporate microsimulation model ZEW TaxCoMM (Finke et al. (2013)). We illustrate the heterogeneous impact of this reform on firm-level tax payments and compute aggregate revenue effects. Moreover, we determine the corporate income tax rate required to compensate primary tax base effects on the aggregate revenue and trace the consequences for the tax burden at firm level. Finally, we augment the analysis by taking behavioural responses into account.

Approaches based on the neoclassical investment theory (Hall and Jorgenson (1967), King and Fullerton (1984), Devereux et al. (2002)) consistently reveal the distortions which an ACE regime potentially induces at the various behavioural margins. A strictly microe- 
conomic foundation, however, prevents those models from being applicable for purposes other than the identification of tax incentives on representative agents. Furthermore, general equilibrium models were successfully applied to evaluate the impact of an ACE regime on welfare (Fehr and Wiegard (2003), Keuschnigg and Dietz (2007), Radulescu and Stimmelmayr (2007), de Mooij and Devereux (2011), Oropallo and Parisi (2005)). Since those models usually also resort to representative agents calibrated according to national accounts data, the truly existing firm-level heterogeneity with respect to business and tax status is also underrepresented in those approaches. As a result, any in-depth analysis of tax reform consequences with respect to tax revenue at various levels of aggregation or micro-level tax effects is hardly feasible on the basis of those models. Still, policy makers accord outstanding relevance to these issues since they constitute crucial determinants for the feasibility and sustainability of tax systems. For this reason, we follow a different approach and proceed real micro-level accounting data in order to calculate firm-specific taxes due under the two opposing tax policy scenarios. Using behavioural corporate microsimulation model, we are able to quantify the reform consequences for a business population of firms which, according to their individual business and financial status, are hit by these tax policy measures in different ways. Our paper provides an ex-ante evaluation of an ACE tax regime in comparison to the German tax system of 2012. In contrast to most existing simulation studies which focus on welfare implications we concentrate on the corporate sector but capture the heterogeneity of firms at the micro level. Accordingly, our contribution will be an in-depth analysis of tax reform consequences with respect to the heterogeneous impact of the reform on companies of different characteristics and a comprehensive analysis of tax revenue effects including behavioural responses. The firm's heterogeneity is relevant in two regards. Firstly, revenue consequences and the tax rate adjustment required for constant revenues should reflect the fact that firms making losses under both regimes do not pay taxes at all and are therefore not concerned by a change in regimes. Secondly, for the viability of the reform, it is important to know how the benefits or disadvantages of the considered tax regime are distributed across the sample of corporations in Germany and how they are related to firm specific characteristics. The scope of our analysis goes beyond an analysis of pure tax burden effects since we also compute changes in tax revenue and derive the tax rate required to balance these changes. Taking firms' behavioural responses into account, we show that responses at the profit-shifting and location decision margin can be substantial thus preventing the ACE regime with adjusted tax rates from being revenue neutral.

The remainder of the paper is organized as follows. Section 2 introduces the idea of an ACE regime, highlights relevant features of this concept and summarizes existing studies to evaluate their respective impact. Section 3 sketches the behavioural corporate 
microsimulation model ZEW TaxCoMM and describes the underlying data-set. In Section 4, the ZEW TaxCoMM will be employed to evaluate the impact of introducing an ACE regime in Germany with respect to the German tax system of 2008. Section 5 concludes.

\section{Idea of an ACE regime and existing evidence}

The benefits of decision neutral tax system have been discussed intensively in the literature. A tax system is considered neutral if behavioural decisions remain unaffected by taxation (Atkinson and Sandmo (1980)). This ensures that the optimal allocation of resources is not distorted by taxation and no welfare-reducing excess burden arises (Musgrave (1959). Although the positive features of decision neutrality have been recognized by policy makers, conventional corporate income tax systems are usually non-neutral.

With respect to financing decisions, interest on debt is generally deductible from corporate taxable income while return on equity is not. One of the main concerns regarding this so-called debt-bias is that it drives up leverage ratios thus increasing the risk of insolvency and exacerbating the consequences of economic downturns (Bianchi (2012)). In addition, welfare costs arise if high leverage ratios induce inefficiently high extra costs of if the access to the tax privileged source of finance differs between firm typs thus distorting capital allocation (de Mooij (2011)).

Current tax systems do not only distort financing decisions but also affect the volume and ranking of investment alternatives. These distortions can result in general underinvestments or investments into less-productive assets and are thus welfare reducing (Devereux and Freeman (1991)).

Given these shortcomings of actual tax systems, different concepts have been derived which realize neutrality principles. Within a concept of comprehensive income taxation at uniform rates, the taxation of economic profits ensures tax neutrality by tying tax depreciation to economic depreciation (Johansson (1969)). In contrast to this system, in which interest income is taxable, the systems of cash-flow taxation (Brown (1948)) and allowance for corporate equity (Boadway and Bruce (1984), Boadway and Bruce (1979)) exempt interest from taxation and are hence classified as consumption tax systems. In an ACE regime, the deduction of a normal return on equity reduces the tax base. It can be shown that this is in present value terms equivalent to granting immediate deduction of investment expenses as it is the case in a cash-flow regime (Boadway and Bruce (1984)). Both system tax only economic rents, while the normal return on investment is shielded from taxation regardless of the source of financing. It thus neither marginally distorts corporate investment nor financing decisions (Institute for Fiscal Studies (1991)). Nonetheless, since the notional interest 
deduction narrows the corporate tax base, the ACE regime entails tax revenue losses that might need to be financed. Revenue neutrality can be achieved by trading the zero tax on the normal return on capital off against a higher tax rate on economic profits. In view of significant international tax differentials and high capital mobility, a higher corporate tax rate might, however, affect location choices negatively and increase the risk of profit shifting activities (Bond (2000)). Moreover, since the ACE system constitutes in essence a tax on economic rents, firms with low profitability pay little taxes and the tax burden is shifted to highly profitable firms, which are mostly multinational enterprises (Isaac (1997)).

Since the theoretical foundations of the ACE regime were developed by Boadway and Bruce (1979) and Wenger (1983), there have been several theoretical studies on the effects of granting equity allowances. Primary empirical evidence, in contrast, is rather scarce since only a few countries have introduced ACE type of tax reforms.

Staderini (2001) finds empirical evidence that the Italien ACE type of reform induced a reduction in debt-to-asset ratios. Klemm (2006) focuses on the ACE regime in Brazil, which was introduced for a minority of firms and only on distributed profits. Simultaneously, the corporate income tax rate was reduced. Hence, the results are not clear cut but suggest that investments benefited from the reform. Moreover, the author finds that capital structures have not changed much whereas dividends increased. Kestens et al. (2012) investigate whether the notional interest deduction in Belgium affected the capital structure of Belgian SMEs and find supporting evidence for a negative relationship.

Fehr and Wiegard (2003) quantify the efficiency and distributional effects of introducing an ACE system with reference to the German tax system of 1996. In addition, they combine a corporate ACE regime with a tax relief on private savings at the household level. The authors employ an overlapping generations model, which allows them to identify intergenerational redistribution effects of the proposed reform. According to their simulations, the combination of ACE with tax exempt savings income is clearly beneficial for young and future generations but at the expense of the elderly. Moreover, they find aggregate efficiency effects of $10 \%$ of the reform year's total tax revenue.

Keuschnigg and Dietz (2007) focus on Switzerland and use a general equilibrium model to simulate the efficieny effects of a dual income tax which combines an ACE regime with a broadly defined flat tax at shareholder level. Within their simulation, they ensure revenue neutrality via an increase of the VAT rate by $4 \%$ in the long run. The simulation reveals a reduction in the average debt asset ratio of 1 percentage point compared to the status quo. The cost of capital decrease by 1.1 percentage points and increasing investments translate to a permanent increase of GNP between 4 and 5 percent in the long run.

Radulescu and Stimmelmayr (2007) investigate welfare implications of switching from 
the German tax system of 2007 to either an ACE or CBIT tax system. They determine the welfare effects of the hypothetical reform scenarios on the basis of a dynamic general equilibrium model (IfoMod). The model includes two countries, a corporate and a noncorporate sector, an infinitely lived agent, the government and the "Rest of the World". The representative firm is calibrated according to German macroeconomic key data and follwos neoclassical investment and production patterns. The model accounts for dynamic interactions between its building blocks and for behavioural responses to a changing tax framework with respect to financing and investment decisions. The authors find that an ACE reform is slightly welfare improving $(+0.08 \%)$ if revenue losses are financed by an increase in value added tax (VAT) of 5.1 percentage points, due to the cost of capital decreasing by $6.3 \%$ and thus stimulating an increase in capital stock by $20 \%$ in the long run. According to Radulescu and Stimmelmayr, it is not possible to find a corporate tax rate which would be high enough to balance the revenue deficit induced by the ACE. Moreover, the authors determine positive welfare impacts for a CBIT regime $(0.02 \%)$ in case it is accompanied by an immediate write-off of investment expenses and an exogenous adjustment of the corporate income tax rate.

de Mooij and Devereux (2011) study the trade-offs in ACE and CBIT tax regimes for Europe. They apply an international general equilibrium model (CORTAX), which is conceived to simulate the economic implications of domestic and international corporate tax policies. The geographical coverage extends to the EU 27 countries as well as the US and Japan. In each country the firm sector is represented by one domestic and one multinational headquarter owning a subsidiary in each foreign country. The multinational structure of corporations allows considering profit-shifting activities. Parameters describing the national tax systems of 2007 are corporate income tax rates, local taxes, surcharges and the net present value of depreciation allowances. The determination of the tax base resorts to national accounts data on gross value added minus labour income. Average country specific debt-to-asset ratios are taken from the ORBIS database. The model simulates various decision margins of the firms, concerning financial structure, investments, profit allocation and discrete location choice. De Mooij and Devereux find that with adjustment lump-sum transfers but constant profit taxes, the ACE regime is welfare improving in all countries (EU average: $0.6 \%$ ) and the CBIT regime reduces welfare in all countries (EU average: $0.7 \%$ ). In a next step the profit tax rate is increased to keep the tax revenue unchanged with respect to the reference tax system ex-ante, i.e. before behavioural effects are taken into account. In this scenario, the ACE regime becomes welfare reducing $(-0.2 \%)$ and the CBIT regime becomes more attractive (0.7\%). In the context of a revenue neutral ACE regime, the average increase of the profit tax rate is 17 percentage points. This increase 
leaves marginal investments unaffected but reduces welfare due to profit shifiting and discrete location choices. Moreover, CORTAX shows that a revenue-neutral combination of ACE and CBIT reforms is slightly welfare improving (0.2\%) since it reduces distortions of financing decisions. Finally, the authors investigate a coordinated introduction of an ACE regime in Europe. The coordination reduces fiscal spillovers from tax rate competition, thus mitigating the negative effects of financing an ACE regime via a rise in profit tax rates. Hence, according to the CORTAX results, a simultaneous introduction of an ACE in Europe ensures that the system is welfare improving $(0.4 \%)$.

Oropallo and Parisi (2005) employ a microsimulation model (DIECOFIS) to simulate ex-post how the abolition of the Italian Dual Income Tax system has affected the firm specific tax burden. Their results show an increase in the mean tax burden of 0.26 percentage points but with strong variation across sectors.

\section{Methodology and Data}

For our analysis we apply the behavioural corporate microsimulation model ZEW TaxCoMM (Finke et al. (2013)). The basic idea of the model is to derive tax payments for a reference and reform scenario from a broad firm-level dataset of financial accounts. The first step consists of adjusting the available data according to the tax code of a reference tax regime (Reister (2009)). This includes for example reversing deductions in financial accounts that are prohibited for tax accounts (e.g. profit taxes, parts of interest expenses), taking into account tax exempt income (e.g. received dividends) or ajusting for differences in the valuation and recognition of certain balance sheet items (e.g. provisions). In a next step, a tax reform, here the ACE regime, is simulated and the results are compared to the firm specific tax payments derived under the reference scenario. The firm level effects are aggregated determine tax revenue effects. To assess reform consequences comprehensively, the model takes behavioural responses to changes in tax incentives into account (for a detailed description please refer to Finke et al. (2013)). At the micro-level, we consider the extent to which tax law changes affect firms' financing structure, marginal investments, and profit shifting activity. Since we take the number of firms in our dataset as given, we consider tax effects on location choices on the aggregate revenue level only. The exent to which reforms induce behavioural responses is driven by two major determinants. Firstly, we measure to which extent the reform affects the respective tax incentive for each decision margin. Here we assume that investements respond to changes in the cost of capital whereas the financing structure is sensitive to the value of the tax shield (i.e. the tax advantage of debt compared to equity). Profit-shifting responses are attributed to changes in the difference between the 
domestic profit tax rate and foreign tax rates. Secondly, the extent to which changes in tax incentives affect real economic responses clearly depends on the firms' sensitivity two tax law changes. A broad empirical literature measures the responsiveness of firms at various decision margins. The model calibration of ZEW TaxCoMM is based on comprehensive quantitative assessment of the existent evidence in terms of meta-analyses for each decision margin (Heckemeyer (2012)). In the context of our microsimulation analysis this ensures that elasticities are not arbitrarily taken from one study but take the broader evidence into account. Moreover meta-regression approaches allow for extracting elasticities for different firm types (e.g. multinational vs. domestic firms).

The major data source are balance-sheet data, profit-and-loss account data and ownership data from the DAFNE database of Bureau van Dijk. DAFNE contains detailed financial information of German corporations. Our microsimulation database covers the years from 2005-2007. The simulation procedure requires the underlying data panel to be balanced. Hence, only corporations with balance sheets as well as profit and loss accounts for this entire time span are included in the sample. ${ }^{1}$ Eventually, the sample includes 25.626 companies, i.e. 76.878 firm-year observations. This is of course only part of the entire population of corporations in Germany. In order to smooth out structural differences between the microsimulation sample and the population of all corporations in Germany, data and results from the considered sample are extrapolated. For this purpose, we principally proceed along the lines of the method applied by the German Central Bank to extrapolate financial accounts data from a sample of German corporations to the total business population. Yet, while the Central Bank resorts to official turnover statistics, the extrapolation here is based on the corporate income tax statistics of 2006 provided by the German Federal Statistical Office (Statistisches Bundesamt (2011)). The extrapolation ensures that structural distortions of the sample due to less prominently represented small and medium-sized corporations or underrepresented sectors are offset. Accordingly, ZEW TaxCoMM allows for conclusions on the distribution of the tax burden among corporations as well as on revenue implications of tax reforms. Table 1 illustrates the structure of the extrapolated sample.

Table 1 illustrates the structure of the extrapolated sample. The share of large corporations amounts to $5.71 \%$. Medium-sized corporations account for $16.46 \%$ of the sample. The largest share of firms $(77.83 \%)$ are qualified as small corporations. So sind nun 44,28\% der Unternehmen den wirtschaftlichen Dienstleistungen zuzuordnen. With respect to the industry coverage, the largest share of firms belongs to the trade, hotel and restaurant industry $(21.47 \%)$ and the manufacturing sector $(13.44 \%)$. The smallest industry in the sample is the health sector. Corporations belonging to the finance sector are not included in the sample.

\footnotetext{
${ }^{1}$ Non-tax-paying charitable companies are excluded from the dataset.
} 
Table 1: Structure of the extrapolated sample

\begin{tabular}{|c|c|c|c|c|}
\hline Industry & Small & Medium-Sized & Large & Total \\
\hline Manufacturing, Mining & 75,24 & 31,137 & 9,196 & 115,573 \\
\hline Energy, Water & 4,83 & 2,186 & 2,053 & 9,07 \\
\hline Contstruction & 77,771 & 11,308 & 1,904 & 90,983 \\
\hline Trade,Hotels,Restaurants & 134,87 & 44,528 & 7,467 & 186,865 \\
\hline Transport, Communication & 24,695 & 4,781 & 1,486 & 30,961 \\
\hline $\begin{array}{l}\text { Business Services, R\&D, } \\
\text { Technical Services }\end{array}$ & 326,903 & 34,391 & 19,379 & 380,673 \\
\hline Health & 13,284 & 10,215 & 6,18 & 29,679 \\
\hline Other & 11,479 & 2,939 & 1,408 & 15,826 \\
\hline Total & 669,071 & 141,484 & 49,073 & 859,63 \\
\hline Share of firms & $77.83 \%$ & $16.46 \%$ & $5.71 \%$ & \\
\hline
\end{tabular}

\section{The Effects of Introducing an ACE regime}

\subsection{Implementing the ACE regime into the model}

The current German tax regime constitutes the reference tax system. In the course of the latest tax reform in 2008, the corporate income tax rate was reduced to $15 \%$. The reference tax system does not yet include any allowances for equity. In contrast, the earningstripping rule, which was newly introduced in the course of the tax reform 2008, under certain conditions restricts the deduction of interest expenses to $30 \%$ of EBITDA. Besides corporate income tax, a local trade tax is levied. The tax rate depends on municipal multipliers and amounts to $14 \%$ for an average multiplier of $400 \%{ }^{2}$ Since the computation of the local trade tax, in a first step, takes over the taxable base of the corporate income tax, ${ }^{3}$ the restricted deductibility of interest expenses persists also for trade tax purposes. Moreover, 25\% of interest expenses are added back to arrive at the trade tax base. This encompasses deemed interest expenses included in rents, licences and leasing fees that reduced the tax base of corporate income tax. An exemption limit of EUR 100,000 applies. Since other elements of the tax base are not affected by the reform scenarios, we abstain from a detailed description here.

Starting from this reference tax system, the integral part of implementing an ACE regime consists in defining the equity basis qualifying for the allowance and in fixing the applicable rate of return. With respect to the equity basis, the allowance can either be based on the existing equity stock or new equity accumulated after introducing the ACE regime. For our analysis, we consider the equity stock. Compared to the more restrictive variant, our result will therefore consitute the upper-bound of the effects. The equity basis is reduced by the book value of participations held in order to avoid double counting. With respect to the normal rate of return on equity, we assume a rate of $2.65 \%$. This rate corresponds to rate of

\footnotetext{
${ }^{2}$ In the simulation we apply the multiplier which applies in the municipality where the firm operates.

${ }^{3}$ Several adjustments have to be made because certain expenses are deductible from the corporate income tax base but not from the trade tax base and vice versa.
} 
10-year German government bonds in 2011 (Deutsche Bundesbank (2012)). If the allowance exceeds taxable profits in one period, we consider a carry-forward of the allowance. The ACE concepts requires interest expenses to be deductible from the corporate tax base. In contrast to the reference tax system, we therefore do not consider any earnings-stripping regulations for the ACE regime. The neutrality features of the ACE regime require a direct loss-compensation or interst-bearing loss carry-forward. It can, however, be shown, that this is equivalent to not considering losses in the computation of the equity basis. We follow this latter approach. Other adjustments of the tax base are not necessary, since by nature of the ACE regime the effects of accruals and timing differences of tax base regulations are offset. Implementing the ACE in Germany does not necessarily require the abolishment of the trade tax. Its current regulations, especially the add-back of interest-exepenses, is not compatible with the ACE regime. We therefore consider an identical tax base of corporate income tax and trade tax for the purpose of the ACE regime.

\subsection{Tax Revenue Consequences}

As a primary output, ZEW TaxCoMM calculates the annual tax due at the level of each firm. Please note that all results presented in this Section 4 do not take behavioural responses of firms into account because the major aim is to understand whether and to what extent the pure regulations of an ACE reform treat firms differently according to their economic and financial characteristics at status quo. Introducing an allowance for corporate equity clearly narrows the tax base. If revenue neutrality is supposed to be a major prerequisite for the reform, the effects of narrowing the tax based need to be offset. Therefore, our analysis proceeds as follows. First we compute the revenue consequences of introducing an ACE in Germany taking the current tax system as a reference. From these effects, we compute the tax rate required to offset the primary revenue losses induced by the narrowing of the tax base due to the equity allowance. Based on this, we illustrate the micro-level reform effects for both, the pure ACE reform and the ACE reform with adjusted tax rate. In a second step, we augment the analysis by taking behavioral responses to the ACE reform with adjusted tax rate into account.

Table 2 illustrates the revenue consequences of introducing an ACE regime. For the reference tax system 2012 the total revenue arising from corporate income tax, trade tax and solidarity surcharge amounts to 49.174 bn Euro (3-year average over the considered years). The tax revenue declines to 40,123 bn Euro if the allowance for corporate equity is introduced. This is a revenue loss of 9.051 bn Euro or $18.4 \%$. The revenue loss is an outcome of substantially narrowing the tax base by introducing the allowance for corporate equity and by abolishing the restricted deductibility of interest expenses for corporate income tax 
and trade tax.

Table 2: Revenue effects of introducing an ACE and tax rate adjustment required to offset these effects

\begin{tabular}{lcc}
\hline Tax System & $\begin{array}{c}\text { Reference } \\
\text { system }\end{array}$ & ACE regime \\
\hline Total Revenue (bn Euro) & 49.174 & 40.123 \\
Absolute Change (bn Euro) & & -9.051 \\
Relative Change (\%) & & $-18.4 \%$ \\
Required Tax Rate Adjustment & & $6.37 \%$-points \\
\hline
\end{tabular}

Note: Calculations are based on economic data from 2005-2007. The presented results summarize the average effect over the considered years. Source: ZEWTaxCoMM.

As shown above, introducing an ACE regime is per se clearly not revenue neutral. Therefore we compute the profit tax rate required to compensate for the narrowing of the tax base. ${ }^{4}$ The results in table 2 show, that increasing the combined tax rate on profits by 6.37 percentage points would set off primary tax revenue losses. This increase seems rather moderat, given the results of earlier studies and the huge concerns brought forward against an ACE regime that it would require insustainably high profit tax rates. Comparing our results to other recent results for Germany, de Mooij and Devereux (2011) use the applied general equilibrium model CORTAX and calculate a required increase of the combined German profit tax rate by approximately 15 percentage-points to set-off first round tax revenue losses. This is more than twice the effect determined here. One reason for this difference is that de Mooij and Devereux (2011) refer to the 2007 German tax system with benchmark tax rate on corporate profits of $38.7 \%$. Clearly, departing from a higher benchmark tax rate implies that an equity allowance generates higher revenue losses. It thus requires a higher compensating increase of the profit tax rate. Furthermore, ZEW TaxCoMM computes the revenue consequences of the ACE regime in a bottom-up approach and thus precisely accounts for firm-specific debt-to-assets ratios as well as the firm-specific amount of taxabel profits or losses. CORTAX, in contrast, uses national acocunts date on gross vlaue added minus total labour income to determine revenue effects and an average debt ratio to measure the extent of equity allowances.

\subsection{Micro-level tax effects of introducing an ACE}

Having derived the required increase in the profit tax rate from the aggregate revenue effects, we will now illustrate firm level consequences of introducing an ACE regime and a revenue neutral ACE regime. We consider the revenue neutral regime (i.e. granting an ACE and

${ }^{4}$ Other options of financing an ACE reform would include levying other taxes or increasing the value added tax. Here, however, we focus on a solution within the profit taxation of firms. 
increasing the profit tax rate by 6 percentage points) as more realistic. ${ }^{5}$ To isolate the respective impact of granting the allowance and of increasing the tax rate, we will in the following oppose both scenarios. Table 3 illustrates the distribution of micro-level tax effects of introducing the ACE.

Table 3: Distribution of the tax effects of introducing an ACE (with constant tax rate) (in $\%$ of tax payments in the reference system)

\begin{tabular}{|c|c|c|c|c|c|c|c|c|c|}
\hline $\begin{array}{l}\text { Percentile of the } \\
\text { Distribution }\end{array}$ & $1 \%$ & $5 \%$ & $10 \%$ & $25 \%$ & $50 \%$ & $75 \%$ & $90 \%$ & $95 \%$ & $99 \%$ \\
\hline $\begin{array}{l}\text { Change in tax payments } \\
\text { by ACE }\end{array}$ & -100 & -70 & -62 & -35 & -15 & -2 & 0 & 0 & 4 \\
\hline
\end{tabular}

Since introducing the ACE narrows the tax base, the vast majority of firms face a decline in tax payments. On average, the tax savings amount to $23 \%$. This reduction is, however, very heterogeneously distributed accross the sample. For $50 \%$ of firms in the middle of the distribution, i.e. between the 25 th and 75 th percentile, tax payments are reduced between $35 \%$ and $2 \%$. The median firm experiences a decline in tax payments by $15 \%$. For $10 \%$ of firms, the decline in tax payments exceeds $62 \%$. The reduction amounts to $100 \%$ for about $1 \%$ of firms which do not pay any taxes under the ACE regime since deducting the allowance for those firms results in a tax payment of 0. Firms making losses in all three years can neither benefit from the periodic deduduction of the equity allowance nor from its carry forward and their tax payments therefore remain unchanged. In single cases (about $2 \%$ of firms) tax payments increase. This effect can be attributed to the assumption that the trade tax under the ACE regime is applied to the tax base of the corporate income tax. For firms showing an overall increase in tax payments the change in the trade tax base (e.g. deduction of $1.2 \%$ of the standard value of immovable property) offsets the effects of the ACE.

Considering the revenue neutral ACE regime in which the allowance is financed by an increase of the profit tax of about 6 percentage points, Table 4 shows that the trade-off between an increased tax rate and the allowance is quite heterogeneous across firms.

The median firm does no longer experience a reduction in tax payments as opposed to the pure ACE regime. For $50 \%$ of firms in the middle of the distribution (between 25th and 75 th percentile) the reform induced change in tax payments is between $-32 \%$ und $+7.1 \%$. Despite the increase of the tax rate, a large share of firms still benefits from this revenue neutral type of ACE reform.

\footnotetext{
${ }^{5}$ Please note that this tax system is only revenue neutral with respect to primary effects of changing the tax code. We will show at a later stage of this study that behavioural responses will prevent this system (ACE with increased tax rate) from being revenue neutral.
} 
Table 4: Distribution of the tax effects of introducing an ACE (with adjusted tax rate) (in $\%$ of tax payments in the reference system)

\begin{tabular}{|c|c|c|c|c|c|c|c|c|c|}
\hline $\begin{array}{l}\text { Percentile of the } \\
\text { Distribution }\end{array}$ & $1 \%$ & $5 \%$ & $10 \%$ & $25 \%$ & $50 \%$ & $75 \%$ & $90 \%$ & $95 \%$ & $99 \%$ \\
\hline $\begin{array}{l}\text { Change in tax payments } \\
\text { by revenue neutral ACE }\end{array}$ & -100 & -67 & -65 & -32 & 0 & 7.1 & 17.5 & 21 & 25 \\
\hline
\end{tabular}

Table 5 illustrates the fact that a large share of firms still benefits from an ACE regime even if the tax rate is increased. Precisely, the share of reform "winner"' is still $50 \%$, as opposed to $81 \%$ in the non-neutral scenario (see table 5). Firms showing no change in tax payments are loss-making in all three periods.

Table 5: Share of firms gaining or losing from an ACE or a revenue neutral ACE

\begin{tabular}{rccc}
\hline Scenario & Winner & Loser & Unchanged \\
\hline ACE & $81 \%$ & $2 \%$ & $17 \%$ \\
Neutral ACE & $50 \%$ & $34 \%$ & $16 \%$ \\
\hline
\end{tabular}

The different size of reform effects across the sample raises the question what about the major drivers of this heterogeneous reform impact. Put differently, how are firms characterized which show a strong reduction in tax payments and in return, which firms are losing from especially the revenue neutral type of ACE reform.

The ZEW TaxCoMM allows us to establish a direct link between the reform effects and major firm characteristics. Clearly, when considering ACE regimes, profitability and leverage ratio can be expected to have a strong impact on the reform effects. To illustrate the relationship between these characteristics and the reform effect, firms are assigned to one of four quarters of the distribution according to their specific reform impact (resulting from the respective distributions in table 3 and table 4). For each quarter, we compute the median of profitability and leverage ratio and display the results in table 6 for the ACE regime and table 7 for the revenue neutral variant. This comparison highlights that firms in the first quarter, i.e. with the highest reduction in tax payments, are characterized by a moderate profitability $(2.65 \%)$ and a comparably low leverage ratio (51.2\%). This group of firms has a high share of equity and thus the allowance for corporate equity is higher in absolute terms. At the same time, the allowance has a stronger impact on the tax base, since these firms show only a moderate profitability, compared to the third quarter including firms between the 50th and 75th percentile (median profitability 5.94\%). Generally, the impact of regulations determining the tax base is declining with increasing profitability of firms and such is in principle the impact of the ACE. Taking more than one period into account, 
however, high profits, if retained, increase a firm's equity and thus the base for calculating the allowance in future periods. That is why firms showing a very low profitability and at the same time a high leverage benefit least from the reform. The reduction in tax payments within this group of firms does not exceed $2 \%$. To some extent this effect is also driven by those firms which are not at all affected by the ACE reform because of persistent tax losses.

Table 6: Matching up firm-level tax effects of an ACE (with constant tax rate) with financial ratios

\begin{tabular}{|c|c|c|c|}
\hline $\begin{array}{l}\text { Quarter of the distribution } \\
\text { Change in tax payments }\end{array}$ & $\begin{array}{l}\text { Tax effect } \\
\text { (in \%) }\end{array}$ & Financial ratio & $\begin{array}{l}\text { Median of financial ratio } \\
\text { in the respective } \\
\text { quarter of the distribution }\end{array}$ \\
\hline $\begin{array}{l}\text { Up to } 25 \% \text { Percentile } \\
25 \% \text { to } 50 \% \text { Percentile } \\
50 \% \text { to } 75 \% \text { Percentile } \\
75 \% \text { to } 100 \% \text { Percentile }\end{array}$ & $\begin{array}{c}<-35 \\
>-35<-15 \\
>-15<-2 \\
>-2\end{array}$ & Profitability & $\begin{array}{l}2.65 \% \\
2.51 \% \\
5.94 \% \\
-0.4 \%\end{array}$ \\
\hline $\begin{array}{l}\text { Up to } 25 \% \text { Percentile } \\
25 \% \text { to } 50 \% \text { Percentile } \\
50 \% \text { to } 75 \% \text { Percentile } \\
75 \% \text { to } 100 \% \text { Percentile }\end{array}$ & $\begin{array}{c}<-35 \\
>-35<-15 \\
>-15<-2 \\
>-2\end{array}$ & Debt-Ratio & $\begin{array}{l}51.20 \% \\
57.44 \% \\
61.31 \% \\
73.91 \%\end{array}$ \\
\hline
\end{tabular}

Table 7: Matching up firm-level tax effects of an ACE (with adjusted tax rate) with financial ratios

\begin{tabular}{|c|c|c|c|}
\hline Quarter of the distribution & $\begin{array}{c}\text { Tax effect } \\
\text { (in \%) }\end{array}$ & Financial ratio & $\begin{array}{l}\text { Median of financial ratio } \\
\text { in the considered } \\
\text { quarter of the distribution }\end{array}$ \\
\hline $\begin{array}{l}\text { Up to } 25 \% \text { Percentile } \\
25 \% \text { to } 50 \% \text { Percentile } \\
50 \% \text { to } 75 \% \text { Percentile } \\
75 \% \text { to } 100 \% \text { Percentile }\end{array}$ & $\begin{array}{c}<-32 \\
>-32<0 \\
>0<7.1 \\
>7.1\end{array}$ & Profitability & $\begin{array}{c}1.31 \% \\
0.93 \% \\
4.07 \% \\
7.3 \%\end{array}$ \\
\hline $\begin{array}{l}\text { Up to } 25 \% \text { Percentile } \\
25 \% \text { to } 50 \% \text { Percentile } \\
50 \% \text { to } 75 \% \text { Percentile } \\
75 \% \text { to } 100 \% \text { Percentile }\end{array}$ & $\begin{array}{c}<-32 \\
>-32<0 \\
>0,<7.1 \\
>7.1\end{array}$ & Debt-Ratio & $\begin{array}{l}54.10 \% \\
62.21 \% \\
60.53 \% \\
65.56 \%\end{array}$ \\
\hline
\end{tabular}

Combining the equity allowance with an increase of the profit tax rate by about $6 \%$ affects the firms in the sample differently. The composition of firms in the respective quarters of the distribution is changing. As table 7 points out, the firms' profitability has a stronger impact in this scenario. Most importantly, those firms that benefit from this reform scenario show a very low profitability (median profitability in the first quarter $1.31 \%$ and in the second quarter $0.93 \%$ ) whereas more profitable firms (median profitability $4.1 \%$ in the third and $7.3 \%$ in the fourth quarter) face higher tax payments compared to the status quo. This illustrates one important concern towards an ACE regime that finances the narrowing of the tax base by an increase in tax rates because it shifts the tax burden from less profitable investments to highly profitable investments. But still, as table 7 makes clear, firms with positive profitability can benefit also from a revenue neutral type of ACE reform if the 
leverage ratio is sufficiently low. In particular, this is the difference between firms which experience a decline in tax payments of more than $32 \%$ (median leverage ratio $54.1 \%$ ) and those below (median leverage ratio $62.21 \%$ ).

The impact of the leverage ratio is to some extent compensated by an opposite impact resulting from the full deductibility of interest expenses which was not allowed under the benchmark tax system of 2012 .

\subsection{Taking behavioural responses to the ACE regime into account}

So far, we focused on the direct implications of introducing an ACE regime on tax revenue and firm level tax payments keeping firms' decision making constant. Now, we augment the analysis by behavioural responses induced by the changes in the tax code. We describe our approach to incorporate behavioural responses in section 2 and in Finke et al. (2013). As a first step of this analysis consists, we analyze how the ACE regime affect the incentives for investment, capital structure and profit shifting and to what extent this change induces responses at these decision margins at the micro-level. Second, we compute how these reactions affect tax revenue.

\subsubsection{The extent of behavioral responses to ACE regimes}

Introducing an ACE regime potentially affects different decision margins. Most obviously, the ACE removes the tax advantage of debt financing which prevails in the benchmark tax system and which has largely been criticized. Hence, it is of major interest to what extent the introduction of an ACE regime affects the leverage ratio. Since adjustments of the capital structure potentially cause frictions and thus takes some time, we distinguish between short term and long term responses and assume a stepwise adjustments towards the new optimum. The long term response considers the case in which adjustments towards the optimal leverage ratio under the ACE regime are completed. The results in table 8 illustrate to what extent the ACE regime induces an increase in equity ratios. In the short run (within the first three years after introducing the ACE) the equity ratio increases by 1.5 percentage points on average.

Table 8: Response of the equity-ratio under an ACE regime (in \%-points, 3-years average)

\begin{tabular}{lcc}
\hline Firm type & $\begin{array}{c}\text { Short-term adjustment (\%-points) } \\
\text { Mean }\end{array}$ & $\begin{array}{c}\text { Long-term adjustment(\%-points) } \\
\text { Mean }\end{array}$ \\
\hline All & 1.5 & 5.0 \\
Domestic & 1.5 & 4.9 \\
Multinational & 2.3 & 7.3 \\
\hline
\end{tabular}


The adjustment of the equity ratio varies between 0 and 5.1 percentage points in the short run and up to 16.5 percent in the long run, when adjustment is completed. ${ }^{6}$ The observed effect is driven by the applicable tax rate (which varies according to the municipal multiplier of the firm), the extent of non-deductible interest expenses in the benchmark tax system, the multinational integration of the firm and its profit or loss position. The higher the tax rate, the stronger is the decline in the tax incentive for debt induced by the ACE and the stronger is the increase in the equity ratio. Moreover, empirical studies show that the capital structure of multinational firms is more tax sensitive. That is why we implemented higher marginal effects for multinational firms in the simulation procedure. Consequently, we observe the highest adjustment within the group of multinational firms. Firms with tax losses in at least two periods clearly face different tax incentives, since they do not pay taxes in loss periods and therefore do not benefit from the tax advantage of debt in the benchmark system. Consistently, we assume that these firms do not react to the introduction of an ACE regime. Finally, there is a small group of firms that is unable to deduct interest expenses in the bechmark system due to the German earning-stripping rules and therefore (similar to loss making firms) does not face a tax advantage of debt that could be reduced by the ACE regime. Please note that we do not have to distinguish between the pure ACE regime and the revenue neutral ACE regime here, since the one major feature of the ACE regime is that it abolishes tax distortions of financing decisions. Precicely, a change in tax rates has no further implication on the optimal leverage ratio.

Introducing an ACE regime does not only affect the tax incentive of debt financing but also the effective marginal tax rate (EMTR) of investments. The EMTR is based on the neoclassical investment theory and is particularly apt to capture the tax incentives for marginal investments (King and Fullerton (1984), Spengel (2003), p. 59 ff.). In the benchmark scenario, the EMTR depends on the financing structure, the tax rate, and the relative importance of depreciable assets. Within the ACE system, the EMTR is 0, i.e. the marginal return remains untaxed. By introducing an ACE regime, the tax rate loses its impact on the optimal investment level. Therefore, again, we do not have to consider the ACE regime and its revenue neutral variant separately. Table 9 summarizes the impact of an ACE regime on investment behavior and displays an average increase in capital stocks.

The simulation shows an average increase of the capital stock of $2.4 \%$ in the short run and of $5.5 \%$ after completion of the adjustment process. The increase is smaller for domestic firms since investments of domestic firms have proven to be less sensitive (semi-elasticity of -0.6) with respect to tax than investments of multinational firms (semi-elasticity of 2.59 or

\footnotetext{
${ }^{6}$ For this long run scenario we do not have economic base data. Therefore we compute the change with respect to the mean equity ratio within the three considered years. By doing so, we implicitly assume that the economic framework data remains in the mean unchanged compared to 2005-2007.
} 
Table 9: Capital stock response due to ACE regime (in \% of original value, 3-years average)

\begin{tabular}{lcc}
\hline Firm type & mean (short-term) & mean (long-term) \\
\hline All & 2.4 & 5.5 \\
Domestic & 1.8 & 5.2 \\
Multinational & 13.4 & 29.1 \\
\hline
\end{tabular}

3.89 for most multinational firms). Again, these positive marginal investment effects are not affected by the required increase in the tax rate, since the ACE regime achieves investment neutrality by leaving the marginal return untaxed regardless of the nominal tax rate.

From the perspective of multinational firms there exists an additional decision margin which is avoiding domestic taxes by channeling income to lower taxing jurisdictions via transfer-prifinc or intra-group financing strategies. We do not distinguish between shortterm and long-term responses here by assuming that profit-shifting strategies can be adjusted more easily than the capital stock or the capital structure. The relevant incentive for this profit shifting activity is the nominal tax rate. Due to the increase in the profit tax rate by about 6 percentage points, our simulation yields on average an additional amount of 350.595 Euro shifted. For $1 \%$ of firms the increase in profit-shifting volume is above one million Euro. The effect is more pronounced for multinational firms with a high R\&D intensity since they have a higher degree of discretion in setting transfer prices for their highly specific products. The scale of this effect clearly indicates that considerable revenue effects can be expected.

Considering location choices in a microsimulation framework would require entries or exits from the original sample. To avoid arbirary results we therefore consider the impact of location choices on the aggregate level only.

\subsubsection{Impact of behavioural responses on tax revenue}

So far, we could show that introducing an ACE regime results to considerable responses at the micro level. Now, we are taking into account how the change in behaviour in return affects firms tax payments and the overall tax revenue. Due to the neutrality features of the ACE regime with respect to domestic decision margins, the increase in investments and the reduction of the debt ratio do not entail tax effects. The reduction in debt ratio and interest payments is on the level of the tax base set of against a symetric increase in equity allowances. Similarly, the increase in the capital stock does not affect tax revenue since it is earning the marginal return which is completely shielded from taxation in an ACE regime. ${ }^{7}$ If the

\footnotetext{
${ }^{7}$ Revenue effects results for those cases with a negative EMTR in the benchmark case (due to extremely high debt ratios) which is increased to 0 in the ACE regime. Due to the induced desinvestment, the tax base is reduced by the marinal return that would have been earned in the benchmark case. Since this is different from the costs of financing, there is an additional loss. In total the aggregate affect amounts to $0.2 \%$ of the income in 2012 .
} 
tax rate is increased to offset first-round revenue losses, this leaves investment and financing decisions unaffected. Tax incentives for profit-shifting and location choices are, however, affected negatively. These reaction influence the overall revenue effect (including both tax law changes and behavioral responses) to a significant extent as shown in table 10. The first

Table 10: Revenue effects of behavioural responses

\begin{tabular}{|c|c|c|}
\hline Scenario & $\begin{array}{l}\text { Total revenue } \\
\text { (in bn Euro) }\end{array}$ & $\begin{array}{c}\text { In } \% \text { of reference } \\
\text { tax law }\end{array}$ \\
\hline & \multicolumn{2}{|c|}{ Pure tax code change } \\
\hline 2012 & 49.174 & \\
\hline $\mathrm{ACE}$ & 40.123 & 81.6 \\
\hline \multirow[t]{2}{*}{$\mathrm{ACE}+$ Rate adjustment } & 49.174 & 100.0 \\
\hline & \multicolumn{2}{|c|}{ Behavioural reponse(short-term) } \\
\hline \multirow[t]{2}{*}{$\begin{array}{l}\text { (Debt-Ratio, Investment), } \\
\text { ment) Profit-Shifting }\end{array}$} & 46.901 & 95.4 \\
\hline & \multicolumn{2}{|c|}{ Behavioural response (long-term) } \\
\hline $\begin{array}{l}\text { Profit-Shifting } \\
\text { Location Choice }\end{array}$ & 43.547 & 88.6 \\
\hline
\end{tabular}

three lines indicate the results of a pure change in the tax code while disregarding behavioral responses. Below, we display the effect of short-term reactions which are driven by increased outward shifting activity in view of the higher tax rate. The simulation yields a decline in tax revenue (from corporate income tax, trade tax and the solidarity surcharge) to $95 \%$ of the benchmark revenue. In the long run, the revenue falls to to $89 \%$ of its benchmark value since location choices are affected negatively. Due to adjustment cost we consider location choices to be relevant only in the long-term scenario. Both effects show that contrary to the intention to create a revenue neutral ACE regime by increasing the tax rate, the system turns out to affect revenues significantly if important decision margins such as profit-shifting and location choices are taken into account. Despite the convincing neutrality features for rather domestic decision margins, an ACE regime financed by an increase in profit taxes is distortive with respect to cross-border transactions (investment locations and profit shifting activity).

\section{Conclusion}

The existing tax system in Germany, as in many other countries, distorts firms' decision making at several decision margins. The ACE regime is a potential reform option that removes the tax bias on financing decisions and marginal investment choices. Several coun- 
tries already operate variants of this system. In this study, we briefly sketch how an ACE regime could be integrated into German tax law. Based on these considerations, we use a behavioural corporate microsimulation model ZEW TaxCoMM to quantify the effects of introducing an ACE regime in Germany. Granting an allowance on corporate equity narrows the tax base and, according to our calculations, reduces the German tax revenue (corporate income tax, trade tax, and solidarity surcharge) by $18.4 \%$. Past reforms have shown that revenue costs are highly relevant for the policy-making process. Consequently, options to finance the ACE regime cannot be disregarded. We therefore determine the increase in the profit tax rate required to offset the initial revenue loss. The calculations show that the combined profit tax rate (including corporate income tax rate, trade tax rate and solidarity surcharge) would have to be increased by about 6 percentage points to compensate for the narrowing of the tax base. Taking behavioural responses into account, our computations show that the ACE regime with adjusted profit tax rate cannot be finally revenue neutral. In particular, the increase in the profit tax rate required to finance the equity allowance induces intensified outward profit-shifting activities and affects location choices negatively. In the long-run the tax revenue is therefore shown to decline to about $88 \%$ of its original level. At firm level, our analysis illustrates the heterogeneous distribution of the reform effect accross the sample. For $50 \%$ of firms between the 25 th and 75 th percentile, introducing an ACE regime reduces tax payments between $35 \%$ and $2 \%$. If the ACE is combined with a tax rate adjustment, the tax effect ranges between $-32 \%$ and $+7.1 \%$ for firms between the 25 th and 75th percentile. Matching firm-level tax effects with underlying firm characteristics points out that in the second scenario (ACE + tax rate adjustment) those firms that benefit from this reform scenario show a very low profitability (median profitability in the first quarter $1.31 \%$ and in the second quarter $0.93 \%$ ) whereas more profitable firms (median profitability $4.1 \%$ in the third and $7.3 \%$ in the fourth quarter) face higher tax payments compared to the status quo. This result illustrates how financing the narrowing of the tax base by an increase in the profit tax rate results in a shift of tax burden from less profitable to higher profitable firms. But still, the results also point out that firms with positive profitability can nontheless benefit also from a revenue neutral type of ACE reform if their leverage ratio is sufficiently low. With respect to behavioural responses on decision margins, the simulations shows that introducing the ACE reduces the mean debt-ratio by about 1.5 percentage points in the short run and 5 percentage points in the long-run (after complete adjustment). For the capital-stock we arrive at a mean short-term increase of $2.4 \%$ and a mean long-term increase of $5.5 \%$. 


\section{References}

Atkinson, A. and Sandmo, A. (1980): Welfare Implications or the Taxation of Savings, in: Economic Journal, 90, p. 529-549.

Bianchi, J. (2012): Overborrowing and Systemic Externalitites in the Business Cycle, in: The American Economic Review, 102.

Boadway, R. W. and Bruce, N. (1979): Depreciation and interest deductions and the effect of the corporation income tax on investment, in: Journal of Public Economics, 19, p. 93-105.

Boadway, R. W. and Bruce, N. (1984): A general proposition on the design of a neutral business tax, in: Journal of Public Economics, 24, p. 231-239.

Bond, S. R. (2000): Levelling up or levelling down? Some reflections on the ACE and CBIT proposals, and the future of the corporate tax base, in: Taxing Capital in the European Union. Issues and Options for Reform, Cnossen, S., Editor, Oxford, p. 161-179.

Brown, E. C. (1948): Businessincome taxation and investment incentives, in: Income, Employment, and Public Policy, Essays in Honor of Alvin H. Hansen, Metzler, L., Editor, Norton, New York, p. 300-316.

de Mooij, R. A. (2011): Tax Biases to Debt Finance: Asessing the Problem Finding Solutions, in: IMF Staff Discussion Note.

de Mooij, R. A. and Devereux, M. P. (2011): An Applied Analysis of ACE and CBIT Reforms in the EU, in: International Tax and Public Finance, 18, p. 93-120.

Deutsche Bundesbank (2012): Zeitreihe WT1010: Rendite der jeweils jüngsten Bundesanleihe mit einer vereinbarten Laufzeit von 10 Jahren, Wiesbaden.

Devereux, M. and Freeman, H. (1991): A General Neutral Profits Tax, in: Fiscal Studies, 12 , p. $1-15$.

Devereux, M. P., Griffith, R. and Klemm, A. (2002): Corporate income tax reforms and international tax competition, in: Economic Policy, 17, p. 449-495.

Fehr, H. and Wiegard, W. (2003): ACE for Germany? Fighting for a Better Tax System, in: Steuerpolitik - Von der Theorie zur Praxis, Festschrift für Manfred Rose, Ahlheim, M., Wenzel, H.-D. and Wiegard, W., Editors, Springer, Berlin. 
Finke, K., Heckemeyer, J. H., Reister, T. and Spengel, C. (2013): Impact of Tax Rate Cut Cum Base Broadening Reforms on Heterogeneous Firms - Learning from the German Tax Reform 2008, in: Finanzarchiv, 1, p. 1-41.

Hall, R. E. and Jorgenson, D. (1967): Tax Policy and Investment Behavior, in: American Economic Review, p. 391-414.

Heckemeyer, J. H. (2012): The Effects of Corporate Taxes on Business Behavior, Microsimulation and Meta Analyses, Dissertation Universität Heidelberg.

Institute for Fiscal Studies (1991): A Report of the IFS Capital Taxes Group, Equity for Companies: A Corporate Tax for the 1990s, Commentary, Bd. 26, London.

Isaac, J. (1997): A comment on the viability of the allowance for corporate equity, in: Fiscal Studies, 18, p. 303-318.

Johansson, S. E. (1969): Income Taxes and Investment Decisions, in: Swedish Journal of Economics, 71, p. 103-110.

Keuschnigg, C. and Dietz, M. D. (2007): A Growth Oriented Dual Income Tax, in: International Tax and Public Finance, 14, p. 191-221.

King, M. and Fullerton, D. (1984): The Taxation of Income from Capital - A Comparative Study of the United States, the United Kingdom, Sweden, and West Germany.

Klemm, A. (2006): Allowances for Corporate Equity in Practice, IMF Working Paper, Bd. $\mathrm{WP} / 06 / 259$, Washington.

Mirrlees, J., Adam, S., Besley, T., Blundell, R., Bond, S. R., Chote, R., Gammie, M., Johnson, P., Myles, G. and Poterba, J. (2011): Tax by Design: the Mirrlees Review, Oxford University Press.

Musgrave, R. (1959): The Theory of Public Finance, McGraw-Hill, New York.

Oropallo, F. and Parisi, V. (2005): Will Italy's Tax Reform Reduce The Corporate Tax Burden? A Microsimulation Analysis, SIEP Working Paper No. 403, Pavia.

Radulescu, D. and Stimmelmayr, M. (2007): ACE vs. CBIT? Which is Better for Investment and Welfare?, CESifo Economic Studies, München.

Reister, T. (2009): Steuerwirkungsanalysen unter Verwendung von unternehmensbezogenen Mikrosimulationsmodellen, Gabler, Wiesbaden. 
Sachverständigenrat zur Begutachtung der gesamtwirtschaftlichen Entwicklung (2012): Jahresgutachten 2012/2013, Wiesbaden.

Spengel, C. (2003): Internationale Unternehmensbesteuerung in der Europäischen Union, IDW, Düsseldorf.

Staderini, A. (2001): Tax Reforms to Influence Corporate Finance Policy: the Case of the Italian business Tax Reform of 1997-98, Banca d'Italia Working Paper No. 423.

Statistisches Bundesamt (2011): Körperschaftsteuerstatistik 2006, Sonderauswertung, Wiesbaden.

Wenger, E. (1983): Gleichmässigkeit der Besteuerung von Arbeits- und Vermögenseinkünften, in: Finanzarchiv, 41 n. F., p. 207-252. 